\title{
PENGARUH PELATIHAN, MOTIVASI DAN LINGKUNGAN KERJA FISIK TERHADAP PRODUKTIVITAS KARYAWAN DI HOTEL NATYA KUTA
}

\author{
Putu Aprilia Candra Dewi ${ }^{1}$ \\ I Gede Adnyana Sudibya ${ }^{2}$ \\ ${ }^{1,2}$ Fakultas Ekonomi dan Bisnis Universitas Udayana (Unud), Bali, Indonesia \\ e-mail: apriliacandradewi2@gmail.com
}

\begin{abstract}
ABSTRAK
Meningkatkan produktivitas karyawan adalah salah satu cara yang dapat dilakukan perusahaan untuk unggul dibandingkan pesaingnya. Tinggi rendahnya produktivitas karyawan dapat dipengaruhi oleh beberapa faktor diantaranya pelatihan, motivasi, dan lingkungan kerja fisik. Tujuan penelitian ini adalah untuk mengetahui pengaruh pelatihan, motivasi, dan lingkungan kerja fisik terhadap produktivitas karyawan. Penelitian ini dilakukan di Hotel Natya Kuta. Jumlah responden dalam penelitian ini adalah 59 orang. Teknik analisis yang digunakan dalam penelitian ini adalah regresi linier berganda, uji regresi serempak (Uji F), uji regresi parsial (Uji t) dan koefisien determinasi $\left(R^{2}\right)$. Hasil analisis menunjukan bahwa pelatihan, motivasi, dan lingkungan kerja fisik secara parsial berpengaruh positif dan signifikan terhadap produktivitas karyawan di Hotel Natya Kuta. Sebagai bahan pertimbangan, saran yang dapat diberikan yaitu sebaiknya manajemen hotel Natya Kuta lebih mengawasi dan memberikan dorongan pada karyawan, meningkatkan materi pada saat melakukan pelatihan, dan meningkatkan lingkungan kerja dalam perusahaan dengan menggunakan warna yang dapat menimbulkan kenyamanan saat bekerja.
\end{abstract}

Kata kunci: pelatihan, motivasi, lingkungan kerja fisik dan produktivitas karyawan.

\begin{abstract}
Increasing employee productivity is one way that companies can do to excel than their competitors. The high level of employee productivity can be influenced by several factors such as training, motivation, and physical work environment. The purpose of this study is to determine the effect of training, motivation, and physical work environment on employee productivity. This research was conducted at Hotel Natya Kuta. The number of respondents in this study is 59 people. The analysis technique used in this research is multiple linear regression, simultaneous regression test $(F$ test), partial regression test $(t$ test $)$ and coefficient of determination $\left(R^{2}\right)$. The result of analysis shows that the training, motivation, and physical work environment partially have positive and significant effect to employee productivity at Hotel Natya Kuta. As a matter of consideration, the suggestion that can be given is that the management of Natya Kuta hotel should supervise and encourage employees, improve the material during the training, and improve the work environment within the company by using color that can give comfort while working.
\end{abstract}

Keywords: training, motivation, physical work environment and employee productivity. 


\section{PENDAHULUAN}

Sumber Daya Manusia (SDM) adalah harta atau aset yang paling berharga dan paling penting dimiliki oleh satu organisasi/perusahaan, karena keberhasilan organisasi sangat ditentukan oleh unsur manusia. Pentingnya pengelolaan terhadap SDM disebabkan karena faktor manusia sebagai pelaku utama dalam setiap kegiatan operasional suatu perusahaan. Sebagaimanapun canggihnya sarana dan prasarana yang dimiliki oleh suatu perusahaan tanpa didukung oleh SDM yang berkualitas akan dapat menghambat tercapainya tujuan perusahaan tersebut.

Karyawan adalah aset paling berharga dari setiap perusahaan karena mereka dapat menghancurkan reputasi dan menguntungkan profitabilitas dalam perusahaan. Tanpa pelatihan yang tepat, karyawan tidak akan mampu menerima informasi terbaru dan mengembangkan keahlian yang diperlukan untuk menyelesaikan tugas mereka dengan potensi maksimal, karyawan yang menjalani pelatihan yang tepat cenderung mempertahankan pekerjaan mereka lebih lama daripada mereka yang tidak (Elnaga et al., 2013).

Pelatihan kerja sangat penting dilakukan untuk kepentingan bersama, karena dalam pelatihan kerja awal, karyawan akan mengetahui tugas dan tanggung jawab yang akan ia kerjakan baik secara individu maupun kelompok. Hasil penelitian Penelitian yang dilakukan oleh Singh (2012) menyatakan bahwa pelatihan memiliki pengaruh positif dan signifikn terhadap produktivitas karyawan. Penelitian lainnya yang dilakukan oleh Widianto (2016) menyimpulkan bahwa terdapat hubungan positif dan signifikan antara pelatihan dan produktivitas karyawan. 
Mereka mendapatkan lebih banyak kepuasan dari pekerjaan mereka, tingkat ketidakhadiran yang rendah, produktivitas yang ditingkatkan, bekerja dengan antusiasme, dan mendorong disiplin di kalangan karyawan di sisi lain karyawan yang tidak termotivasi cenderung sedikit atau tidak berusaha pekerjaan mereka, menghindari tempat kerja sebanyak mungkin, keluar dari organisasi jika diberi kesempatan dan menghasilkan karya berkualitas rendah, sehingga perusahaan bisa kehilangan sejumlah besar uang.

Motivasi adalah memberikan kekuatan pendorong yang menciptakan kegembiraan kerja seseorang untuk bekerja sama, bekerja secara efektif dan berintegrasi dengan semua sumber daya dalam pencapaian kepuasan (Hasibuan, M., 2007). Motivasi timbul karena dua faktor: faktor internal yang timbul dari dalam diri sendiri, sedangkan faktor eksternal berasal dari luar (Armstrong, M., 2009). Ada dua jenis motivasi; motivasi intrinsik adalah berasal dari satu diri untuk mempengaruhi orang agar berperilaku dengan cara tertentu. Faktor ini termasuk keingintahuan prestasi, tanggung jawab, otonomi (kebebasan bertindak), pekerjaan dan peluang yang menarik dan menantang kemajuan. Sedangkan motivasi ekstrinsik adalah semacam motivasi untuk memotivasi orang lain. Ini termasuk keuntungan, seperti gaji kenaikan, penilaian, promosi, dan hukuman seperti tindakan disipliner, pemotongan gaji atau kritik

Motivasi yang bersifat membangunkan semangat dan diberikan dengan segala kerendahan hati dan ikhlas akan membuat karyawan melakukan segala pekerjaanya tanpa keluhan dan dengan penuh rasa tanggung jawab. Setiap karyawan memiliki motivasi yang berbeda sebagai dorongan dalam melakukan 
perkerjaanya dengan kerja keras sehingga menghasilkan hasil yang optimal dalam perkerjaanya dan dapat meningkatkan produktivitasnya dalam perusahaan. Putra dan Ardana (2016) menyatakan bahwa adanya pengaruh positif dan signifikan antara motivasi dan produktivitas. Hasil penelitian Chaudhary et al. (2012) juga menyatakan bahwa motivasi berpengaruh positif dan signifikan terhadap produktifitas.

Lingkungan kerja yang baik akan mampu meningkatkan motivasi karyawan untuk bekerja lebih baik lagi sehingga mengingkatkan produktivitasnya dalam perusahaan. Lingkungan kerja yang kondusif dapat tercipta apabila terdapat hubungan yang baik antara individu satu dengan individu yang lainya dan lingkungan fisik yang ada dalam perusahaan sehingga memunculkan efek positif untuk karyawan dan mampu meningkatkan produktivitasnya dalam perusahaan.

Menurut Holle, (2012) penciptaan lingkungan kerja fisik yang baik akan dapat membantu memelihara kondisi fisik sehingga kesegaran fisik karyawan terjaga, tidak cepat lelah, tidak lesu dalam bekerja. Hasil penelitian yang dilakukan oleh Desmonda (2016) menyatakan bahwa adanya hubungan positif dan signifikan antara lingkungan kerja fisik dan produktivitas karyawan.

Bali merupakan daerah wisata favorit yang berada di Indonesia, yang menyebabkan banyaknya pertumbuhan hotel-hotel di Bali sebagai tempat wisatawan untuk menginap. Hotel Natya Kuta sebagai salah satu hotel bintang 4 yang berlokasi di Jl. By Pass Ngurah Rai, Kuta, Kabupaten Badung, Bali. Tingginya tingkat persaingan antara industri-industri perhotelan yang ada, menyebabkan setiap hotel harus memiliki kelebihan atau keunggulan dibandingan 
pesaingnya. Salah satu yang dapat dilakukan hotel untuk unggul dari pesaingnya adalah dengan meningkatkan produktivitas kerja karyawannya dengan maksimal.

Melalui observasi dan wawancara yang telah dilakukan Hotel Natya Kuta memilki jumlah kamar yaitu sebanyak 116 kamar, dimana dalam 116 kamar yang dimiliki, 110 dari jumlah kamar merupakan kamar dengan tipe superior yang dilengkapi dengan twins bed sehingga dalam satu kamar dapat dihuni dengan 2 tamu, dan 6 sisanya merupakan kamar dengan time deluxe. Dalam memenuhi target penjualan hunian kamar Hotel Natya Kuta dibantu oleh karyawan yang memiliki keahlian dan keterampilan yang akan membangun produktivitas di Hotel Natya Kuta menjadi tinggi. Berikut data tentang karyawan yang dimiliki oleh Hotel Natya Kuta.

Tabel 1.

Jumlah Seluruh Karyawan Hotel Natya Kuta Tahun 2017

\begin{tabular}{llc}
\hline No & UNIT KERJA & JUMLAH KARYAWAN \\
\hline 1 & Front Office & 7 Orang \\
2 & Accounting & 5 Orang \\
3 & House Keeping & 20 Orang \\
4 & Engineering & 6 Orang \\
5 & Food and Beverages Kitchen & 8 Orang \\
6 & Food and Beverages Service & 9 Orang \\
7 & Security & 4 Orang \\
& Total & 59 Orang
\end{tabular}

Sumber: HRD Departmement Natya Kuta, 2017

Berdasarkan Tabel 1 dapat diketahui bahwa jumlah karyawan pada Hotel Natya Kuta adalah sebanyak 59 orang, dimana dalam setiap bagian dan jumlahnya berbeda tergantung dengan banyaknya tugas dan bagian yang ada dalam perusahaan. Sumber daya manusia dengan jumlah yang besar dapat membantu menjalankan perusahaan dengan baik apabila dapat didayagunakan secara efektif dan efisien sehingga mampu menunjang gerak lajunya perusahaan berkelanjutan. 
Hal ini juga berlaku untuk Hotel Natya Kuta, apabila perusahaan mampu memanfaatkan sumber daya manusianya dengan baik, maka produktivitas karyawan dalam perusahaan akan meningkat dan mampu memberikan keuntungan yang besar bagi perusahaan.

Tabel 2.

Tingkat Rata-Rata Jumlah Kamar Yang Terjual

\begin{tabular}{ccc}
\hline No & Bulan & Room Occupancy (\%) \\
\hline 1 & Januari & 48,47 \\
2 & Februari & 65,30 \\
3 & Maret & 68,74 \\
4 & April & 54,54 \\
5 & Mei & 73,92 \\
6 & Juni & 63,91 \\
7 & Juli & 72,14 \\
8 & Agustus & 88,32 \\
9 & September & 81,67 \\
10 & Oktober & 82,76 \\
11 & November & 75,49 \\
12 & Desember & 85,76 \\
\hline Sumber: HRD Departement Hotel Natya Kuta, 2016
\end{tabular}

Sumber: HRD Departement Hotel Natya Kuta, 2016

Tabel 2 menunjukan bahwa jumlah kamar yang terjual di hotel Natya ini megalami fluktuasi setiap bulannya, sehingga ini menunjukan adanya ketidakstabilan penjualan kamar, sehingga mampu membuat produktivitas karyawan di hotel Natya Kuta ini menjadi rendah. Dari hasil wawancara yang dilakukan juga ditemukan adanya masalah dengan produktivitas karyawan, dimana karyawan tidak dapat menyelesaikan tugas dengan cepat, dan hasil pekerjaan yang dilakukan tidak sesuai dengan yang diinginkan. Penyebab lainnya yaitu terletak pada penurunan produktivitas karyawan yang disebabkan oleh kualitas kerja tidak sesuai dengan standar perusahaan, berkaitan dengan kurangnya kemampuan karyawan dalam mengerjakan tugas, yang disebabkan oleh kurangnya tersedia pelatihan dan kesempatan untuk belajar yang dapat 
memenuhi standar kebutuhan dalam peruahaan, dan juga pelatihan yang diterima kurang sesuai dengan apa pekerjaan yang diterima.

Faktor lain yang menjadi masalah dalam produktivitas karyawan yaitu disebabkan oleh adanya faktor internal dan eksternal, dimana dalam faktor internalnya yaitu kurangnya motivasi dari karyawannya sendiri untuk bekerja, dimana karyawan kurang inisiatif dalam menyelesaikan masalah, karyawan kurang memiliki keterampilan tertentu dalam perusahaan dan karyawan juga kurang mampu dalam mengarahkan dirinya sendiri untuk menyelesaikan pekerjaannya denga tepat waktu.

Lingkungan kerja fisik karyawan menjadi faktor lain yang mendorong menurunnya produktivitas karyawan dalam Hotel Natya ini yaitu dengan kurangnya perusahaan menyediakan kenyamanan bagi karyawan, seperti contohnya fasilitas yang tidak cukup lengkap dalam perusahaan, dan sarana keamanan yang kurang bagi karyawan. Berdasarkan fenomena yang dibahas tersebut, peneliti tertarik untuk meneliti lebih lanjut tentang "Pengaruh Pelatihan, Motivasi dan Lingkungan Kerja Fisik terhadap Produktivitas Karyawan di Hotel Natya Kuta".

Tujuan penelitian ini untuk menganalisis pengaruh pelatihan, motivasi, dan lingkungan kerja fisik terhadap produktivitas karyawan di hotel Natya Kuta. Penelitian ini memiliki dua maanfaat, yaitu manfaat teoritis dan kegunaan praktis. Manfaat teoritis diharapkan dapat memberi kontribusi studi empiris yang membahas pengaruh pengaruh pelatihan, motivasi dan lingkungan kerja fisik terhadap produktivitas karyawan. Hasil dari penelitian ini juga diharapkan dapat 
menambah informasi dasar dalam pengambilan keputusan dalam perusahaan mengenai produktivitas karyawan di suatu perusahaan.

Kerangka konseptual yang diajukan sebagai dasar penentu hipotesis ditunjukan pada Gambar 1 sebagai berikut.

\section{Gambar 1. Kerangka Konseptual Penelitian}

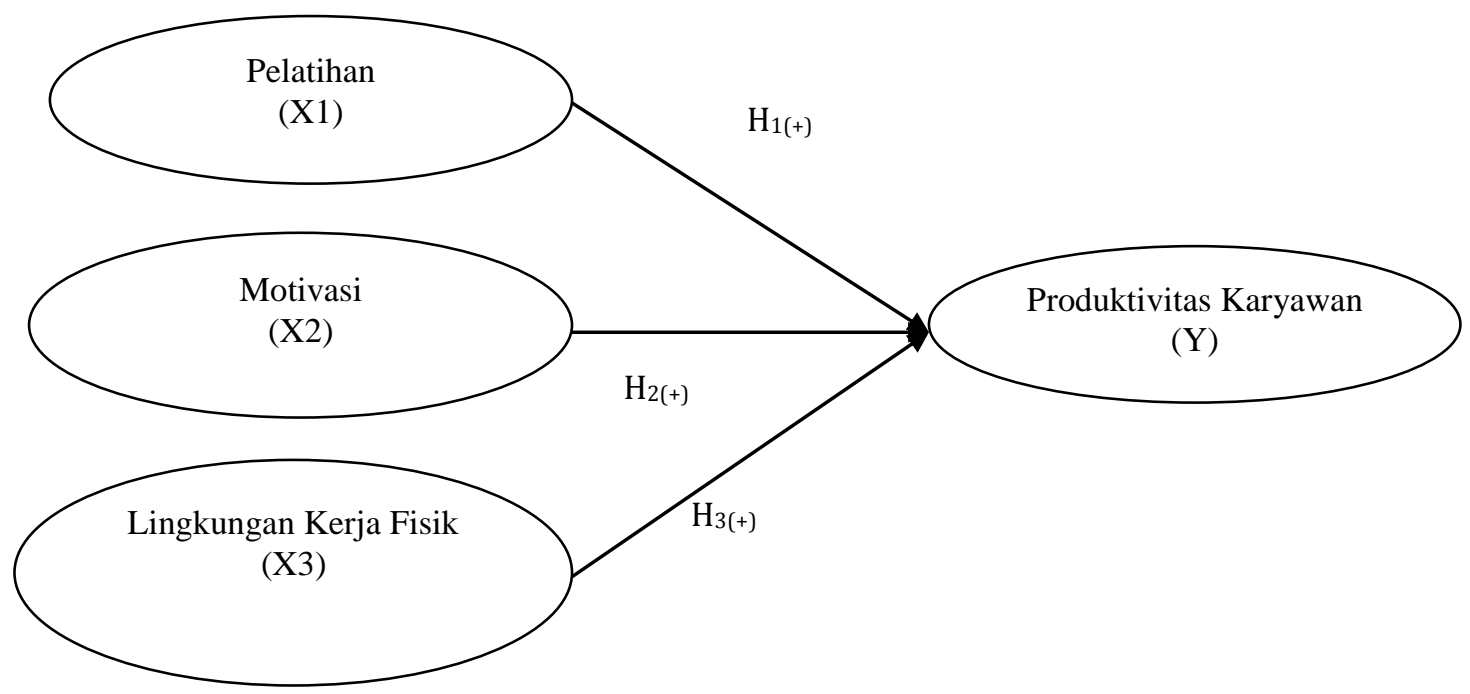

Menurut Sultana et al. (2012) produktivitas digambarkan sebagai kemampuan untuk mencapai tugas-tugas tertentu sesuai dengan standar yang telah ditentukan atau ditetapkan seperti akuransi, kelengkapan, biaya, dan kecepatan. Oleh karena itu tingkat produktivitas setiap karyawan bisa berbeda, bisa tinggi atau bisa juga rendah, tergantung pada segi efesiensi karyawan dalam menjalankan tugasnya. Ferreira dan Du Plessis (2009) menyatakan bahwa produktivitas adalah waktu yang dihabiskan seorang karyawan dalam melaksanakan tugas atau pekerjaanya, dalam rangka mencapai hasil yang diharapkan berdasarkan deskripsi pekerjaanya. Selain itu, Hanaysha (2016) menunjukan bahwa produktivitas karyawan dapat dinilai berdasarkan kuantitas 
dan kualitas kerja yang dilakukan karyawan dengan memperhitungkan biaya yang keluarkan untuk mencapai tujuan dari pekerjaan tersebut.

Pelatihan adalah jenis pembelajaran untuk memperoleh dan meningkatkan keterampilan di luar sistem pengembangan sumber daya manusia yang berlaku dalam periode jangka pendek relatif yang mencakup keseluruhan kegiatan untuk memperoleh, memperbaiki, dan mengembangkan kompetensi kerja, produktivitas, disiplin, sikap dan etika kerja pada tingkat keahlian dan keahlian tertentu sesuai dengan tingkat dan kualifikasi pekerjaan (Sastradipoera, K, 2006). Wibowo (2014:370) menyatakan bahwa pelatihan (training) merupakan investasi organisasi yang penting dalam sumber daya manusia. Pelatihan mampu meningkatkan pengetahuan, dan keterampilan karyawan sehingga perusahaan mampu mendapatkan SDM yang memehui standar perusahaannya.

Biech (2005) menyatakan bahwa pelatihan adalah proses yang dirancang untuk membantu karyawan mempelajari keterampilan, pengetahuan, atau sikap baru. Akibatnya, karyawan tersebut akan membuat perubahan atau transformasi yang akan meningkatkan kinerja. Perbaikan ini memastikan bahwa karyawan dan organisasi mampu melakukan hal-hal yang lebih baik, lebih cepat lebih mudah dengan kualitas yang lebih tinggi dan laba investasi yang lebih baik. Armstrong, M., (2009) menyatakan tujuan dari pelatihan adalah untuk meningkatkan pengetahuan dan keterampilan bahkan untuk mengubah sikap di mana ia dianggap sebagai salah satu yang paling motivator potensial yang penting.

Menurut Kaswan (2011:2), pelatihan adalah proses untuk meningkatkan pengetahuan dan keterampilan karyawan. Pada penelitian yang dilakukan oleh 
Neelam et al. (2014) yang berjudul The Impact of Training and Development on Employees Performance and Productivity A case study of United Bank Limited Peshawar City, KPK, Pakistan diperoleh hasil pelatihan berpengaruh positif dan signifikan terhadap produktivitas karyawan. Penelitian yang dilakukan oleh Konings et al. (2015) yang berjudul The Impact Of Training On Productivity And Wages: Firm-Level Evidence, menunjukan bahwa pelatihan berpengaruh positif dan signifikan terhadap produktifitas karyawan. Penelitian yang dilakukan oleh Singh et al. (2014) yang berjudul Impact of Training Practices on Employee Productivity: A Comparative Study, menunjukan bahwa pelatihan berpengaruh positif signifikan terhadap produktivitas karyawan. Pada penelitian yang dilakukan oleh Sabir et al. (2014) yang berjudul Impact of Training on Productivity of Employees: A Case Study of Electricity Supply Company in Pakistan, menunjukan bahwa pelatihan berpengaruh positif dan signifikan terhadap produktivitas karyawan. Penelitian lain yang dilakukan oleh Widianto (2016) yang berjudul Pengaruh Pelatihan Terhadap Produktivitas Kerja Pegawai menyatakan bahwa pelatihan berpengaruh positif dan signifikan terhadap produktivitas. Jadi hipotesis pertama yang diajukan dalam penelitian ini adalah:

$\mathrm{H}_{1}$ : Pelatihan berpengaruh positif dan signifikan terhadap produktivitas karyawan

Menurut Nnabuife (2009), mendefinisikan motivasi sebagai kekuatan pendorong internal atau eksternal itu menghasilkan kemauan untuk melakukan suatu tindakan sampai akhir yang konklusif. Pada penelitian yang dilakukan oleh Chukwuma et al. (2014) yang berjudul Effect Of Motivation On Employee Productivity in Manufacturing Companies in Nnewi diperoleh hasil Motivasi 
berpengaruh positif dan signifikan terhadap produktivitas karyawan. Khan dan Gautam (2014) yang berjudul A Study of Impact of Motivation on Productivity of Employee diperoleh hasil motivasi berpengaruh positif dan signifikan terhadap produktivitas karyawan. Pada penelitian yang dilakukan Ridwan Purnama yang berjudul Pengaruh Motivasi Kerja Terhadap Produktivitas Kerja Karyawan Pada Bagian Produksi CV. Epsilon Bandung (2008), diperoleh hasil yaitu motivasi berpengaruh positif dan signifikan terhadap produktivitas karyawan. Penelitian lain yang dilakukan oleh Chaudhary et al. (2012) yang berjudul Impact of Employee Motivation on Performance (Productivity) In Private Organization, memperoleh hasil yaitu motivasi berpengaruh positif dan signifikan terhadap produktivitas karyawan. Jadi hipotesis yang diajukan dalam penelitian ini adalah: $\mathrm{H}_{2}$ : Motivasi berpengaruh positif dan signifikan terhadap produktivitas karyawan Menurut Sedarmayanti (2009:26) lingkungan kerja fisik adalah segala keadaan yang berbentuk fisik dan terdapat disekitar tempat kerja yang mempengaruhi cara bekerja karyawan baik secara langsung maupun tidak langsung. Pada penelitian yang dilakukan oleh Sehgal (2012) yang berjudul Relationship between Work Enviornment And Productivity, diperoleh hasil Lingkungan kerja fisik berpengaruh positif dan signifikan terhadap produktivitas karyawan. Pada penelitian yang dilakukan oleh Awan (2015) yang berjudul “Impact of working environment on employee's productivity: A case study of Banks and Insurance Companies in Pakistan" menunjukan bahwa lingkungan kerja fisik memiliki pengaruh positif dan signifikan terhadap produktivitas. Penelitian yang dilakukan oleh Al-Shammari (2015) yang berjudul The Effect of 
Work Environment on Employees' Productivity menyatakan bahwa lingkungan kerja fisik memiliki pengaruh positif dan signifikan terhadap produktivitas karyawan. Penelitian yang dilakukan oleh Lestari dkk. (2013) yang berjudul Pengaruh Pelatihan Kerja, Lingkungan Kerja Fisik Serta Motivasi Terhadap Produktivitas Kerja Pegawai Pada PT. Taspen (Persero) Kantor Cabang Denpasar menyatakan bahwa lingkungan kerja fisik berpengaruh positif dan signifikan terhadap produktivitas karyawan. Selanjutnya penelitian dilakukan oleh Desmonda (2016) yang berjudul Pengaruh Lingkungan Kerja Fisik Terhadap Produktivitas Kerja Karyawan Pada PT. Federal International Finance Cabang Samarinda diperoleh hasil yaitu lingkungan kerja fisik berpengaruh positif dan signifikan terhadap produktivitas kerja karyawan. Jadi hipotesis yang diajukan dalam penelitian ini adalah:

$\mathrm{H}_{3}$ : Lingkungan kerja fisik berpengaruh positif dan signifikan terhadap produktivitas karyawan.

\section{METODE PENELITIAN}

Penelitian ini menggunakan pendekatan kuantitatif yang bersifat asosiatif, untuk meneliti data yang bersifat statistik serta menguji suatu hipotesis, dengan kuesioner berbentuk pertanyaan sebagai instrument yang dipakai. Hal tersebut dikarenakan terdapat hubungan kasual (sebab-akibat) antara variabel bebas $\left(\mathrm{X}_{1}\right.$, $\mathrm{X}_{2}, \mathrm{X}_{3}$ ) yaitu pelatihan, motivasi, dan lingkungan kerja fisik dengan variabel terikat (Y) yaitu produktivitas kerja. Dengan demikian, desain penelitian asosiatif kasual tersebut bertujuan untuk mengetahui kebenaran dari suatu masalah yang terjadi, dengan dilakukan perhitungan analisis data menggunakan teknik analisis yang sesuai dengan penelitian. Lokasi penelitian ini dilakukan di Hotel Natya 
Kuta. Lokasi ini dipilih bertujuan untuk dapat membantu memecahkan masalah mengenai produktivitas kerja karyawan, agar dapat lebih meningkatkan produktivitas karyawan dalam perusahaan ini.

Produktivitas karyawan merupakan kemampuan untuk meningkatkan hasil tugas-tugas yang dicapai sesuai dengan standar yang telah ditentukan atau dengan meminimalkan waktu dan efisiensi karyawan dalam melakukan tugasnya. Menurut Siagian (2002:34) indikator produktivitas karyawan adalah sebagai berikut. 1). Kualitas kerja merupakan hasil yang dicapai karyawan dalam menyelesaikan pekerjaan sesuai dengan standar yang berlaku di perusahaan Indikator ini diukur dari persepsi responden mengenai standar mutu yang tinggi dalam menyelesaikan pekerjaan dan hasil dari pekerjaan selalu berkualitas; 2). Kuantitas Kerja merupakan ukuran yang dicapai karyawan dalam memenuhi standar perusahaan dalam bentuk jumlah yang dihasilkan. Indikator ini diukur dari persepsi responden mengenai mengerjakan sebagaian besar total pekerjaan tiap harinya dan selalu mencapai target yang diberikan dalam tim; 3). Waktu dan kecepatan karyawan untuk menyelesaikan pekerjaanya merupakan jumlah waktu karyawan dalam menyelesaikan tugas yang dibebankan. Indikator ini diukur dari persepsi responden mengenai menyelesaikan tugas dengan cepat.

Pelatihan merupakan sejenis pembelajaran yang terkait dengan kegiatan untuk meningkatkan kemampuan, pengetahuan dan pengalaman karyawan untuk mampu memenuhi standar dan visi misi dalam sebuah perusahaan. Menurut Schmdit (2004) indikator pelatihan adalah sebagai berikut. 1). Dukungan organisasi merupakan dorongan dari perusahaan mengenai pelatihan dalam 
memenuhi kebutuhan karyawan. Indikator ini diukur dari persepsi responden mengenai perusahaan menyediakan kesempatan belajar atau pelatihan dalam memenuhi perubahan kebutuhan tempat kerja; 2). Perasaan karyawan tentang pelatihan merupakan perasaan karyawan mengenai pelatihan yang diberikan perusahaan untuk mengembangkan pengetahuan dan keterampilan karyawan. Indikator ini diukur dari persepsi responden mengenai pelatihan sebagai cara mengembangkan kemampuan dalam bekerja dan pelatihan yang telah diterima sangat aplikatif diterapkan dalam tugas yang dikerjakan; 3). Kepuasan karyawan terhadap pelatihan berkaitan dengan perasaan bangga karyawan terhadap pelatihan. Indikator ini diukur dari persepsi responden mengenai perasaan karyawan yang merasa diuntungkan dengan pelatihan yang diterima dan merasa puas dengan pelatihan yang diterima dalam perusahaan.

Motivasi adalah pemberian semangat atau dorongan untuk mencapai tujuan yang diinginkan. Menurut Kartika dan Kaihatu (2010) indikator motivasi adalah sebagai berikut. 1). Arahan perilaku mengacu pada arah perilaku yang dipilih sesorang dalam mengerjakan pekerjaanya. Indikator ini diukur dari persepsi responden mengenai menjalin relasi yang baik dengan rekan kerja dan taat pada peraturan dalam pekerjaan; 2). Tingkat usaha mengacu pada seberapa keras tingkat usaha seseorang dalam menyelesaikan pekerjaan. Indikator ini diukur dari persepsi responden mengenai inisiatif karyawan dalam memecahkan masalah, memiliki keterampilan dalam bekerja, mampu menghadapi tantangan pekerjaan, dan mengerjakan pekerjaan sebaik mungkin; 3). Tingkat kegigihan mengacu pada kegigihan karyawan dalam menghadapi pekerjaanya. Indikator ini diukur dari 
persepsi responden tentang tanggapan karyawan mengenai pantang menyerah dalam menghadapi pekerjaan, memiliki kegigihan dalam bekerja, mampu mengarahkan diri untuk mengeluarkan segala kemampuan dalam menyelesaikan pekerjaan dan mampu mengarahkan diri untuk menyelesaikan pekerjaan dengan tepat waktu.

Lingkungan kerja fisik adalah keseluruhan keadaan yang terdapat ditempat kerja yang mampu mempengaruhi pelaksanaan pekerjaan. Menurut Sedarmayanti (2010) indikator lingkungan kerja fisik adalah sebagai berikut. 1). Penerangan adalah kondisi pencahayaan yang berada di perusahaan. Indikator ini diukur dari persepsi responden mengenai penerangan yang sudah memadai di tempat kerja; 2). Suhu udara adalah pengaturan sirkulasi udara dalam perusahaan. Indikator ini diukur dari persepsi responden mengenai pengaturan suhu ruangan kerja yang mudah diatur; 3). Suara bising adalah suara yang dapat menggangu didalam perusahaan. Indikator ini diukur dari persepsi responden mengenai tingkat fasilitas yang disediakan mampu memberikan ketenangan dalam bekerja; 4). Penggunaan warna adalah keadaan dalam perusahaan yang memberikan kenyamanan dengan penggunaan warna yang tepat. Indikator ini diukur dari persepsi responden mengenai penggunaan warna yang menarik dalam tempat kerja sehingga menimbulkan kenyamanan dalam bekerja; 5). Ruang gerak yang diperlukan adalah keadaan dalam perusahaan yang memberikan keleluasaan karyawan dalam bergerak. Indikator ini diukur dari persepsi responden mengenai tata letak ruangan kerja yang mempengaruhi aktivitas dalam bekerja dan kebersihan dalam perusahaan mampu membuat ruang gerak yang nyaman dalam perusahaan; 6). 
Keamanan kerja adalah situasi dimana perusahaan memberikan keamanan bagi karyawan dalam bekerja. Indikator ini diukur dari persepsi responden mengenai tersedianya sarana keamanan dalam perusahaan; 7). Hubungan karyawan adalah situasi dimana adanya hubungan yang baik dalam perusahaan antara sesama karyawan atau dengan pimpinan. Indikator ini diukur dari persepsi responden mengenai terjalinya hubungan baik antara sesama karyawan dan antara karyawan dengan pimpinan.

Populasi dalam penelitian ini adalah seluruh karyawan pada Hotel Natya Kuta yang berjumlah 59 karyawan. Teknik pengambilan sampel dalam penelitian ini adalah menggunakan teknik sampel jenuh, dimana sampel yang digunakan adalah seluruh karyawan pada Hotel Natya Kuta, dengan jumlah yaitu sebanyak 59 orang karyawan. Uji yang dilakukan dalam penelitian ini uji asumsi klasik hingga teknik analisis regresi berganda yang menghasilkan bentuk persamaan sebagai berikut.

$$
\mathrm{Y}=\alpha+\beta 1 \mathrm{X} 1+\beta 2 \mathrm{X} 2+\beta 3 \mathrm{X} 3+\varepsilon
$$

Keterangan:

$$
\begin{array}{ll}
\mathrm{Y} & =\text { Produktivitas Karyawan } \\
\mathrm{X} 1 & =\text { Pelatihan } \\
\mathrm{X} 2 & =\text { Motivasi } \\
\mathrm{X} 3 & =\text { Lingkungan Kerja } \\
\alpha & =\text { Konstanta } \\
\beta 1 & =\text { Koefisien regresi Pelatihan } \\
\beta 2 & =\text { Koefisien regresi Motivasi } \\
\beta 3 & =\text { Koefisien regresi Lingkungan Kerja } \\
\varepsilon & =\text { eror }
\end{array}
$$




\section{PEMBAHASAN}

Hotel Natya Kuta merupakan salah satu hotel yang terletak do daerah kuta tepatnya dijalan Bypass Ngurah Rai, Kuta-Bali. Hotel Natya Kuta ini merupakan salah satu bagian dari Coco group. Perusahaan ini didirikan pada bulan Januari tahun 2013 oleh Bapak Nengah Natya yang berasal dari Karangasem. Hotel natya sendiri terdapat beberapa cabang diantaranya di Tanah Lot, dan di Gili Trawangan, di daerah Ubud terdapat Natya Resort dan Natya Residence yang berlokasi di daerah Jimbaran.

Hotel Natya Kuta memilki jumlah kamar yaitu sebanyak 116 kamar, dimana dalam 116 kamar yang dimiliki, 110 dari jumlah kamar merupakan kamar dengan tipe superior yang dilengkapi dengan twins bed sehingga dalam satu kamar dapat dihuni dengan 2 tamu, dan 6 sisanya merupakan kamar dengan time deluxe. Struktur organisasi yang digunakan di Hotel Natya Kuta adalah struktur garis. Struktur organisasi garis merupakan bentuk organisasi yang paling sederhana karena kekuasaan berada pada satu orang pimpinan, dimana pelimpahan kekuasaan (tugas dan wewenang) dilakukan secara vertikal dari atasan kepada bawahan, begitu pula bawahan juga bertanggung jawab secara vertikal kepada atasan.

Hasil penelitian yang dilakukan di Hotel Natya Kuta ini dapat diketahui gambaran tentang karakteristik responden. Uraian tentang karakteristik responden berdasarkan jenis kelamin, tingkat usia, dan tingkat pendidikan. 
Tabel 3.

Distribusi Karakteristik Responden di Hotel Natya Kuta

\begin{tabular}{|c|c|c|c|}
\hline No & Karakteristik & Jumlah (orang) & Presentase $(\%)$ \\
\hline \multirow[t]{4}{*}{1} & Jenis Kelamin & & \\
\hline & Laki-laki & 47 & 79,66 \\
\hline & Perempuan & 12 & 20,34 \\
\hline & Total & 59 & 100 \\
\hline \multirow[t]{6}{*}{2} & Tingkat Usia & & \\
\hline & $20-24$ tahun & 24 & 40,68 \\
\hline & $30-34$ tahun & 20 & 33,90 \\
\hline & $\geq 40$ tahun & 9 & 15,25 \\
\hline & Total & 6 & 10,17 \\
\hline & Tingkat Pendidi & & \\
\hline \multirow[t]{5}{*}{3} & SMA/SMK & 59 & 100 \\
\hline & D1/D2 & 25 & 42,37 \\
\hline & S1 & 28 & 47,46 \\
\hline & Total & 6 & 10,17 \\
\hline & & 59 & 100 \\
\hline
\end{tabular}

Sumber: Data diolah, 2017

Hasil penelitian pada Tabel 3 menunjukkan responden laki-laki sebesar 79,66 persen dan responden perempuan sebesar 20,34 persen. Hal ini menunjukan bahwa responden laki-laki lebih banyak dibutuhkan dibandingkan dengan responden perempuan. Kelompok usia yang paing dominan adalah pada usia 2024 tahun dengan presentase 40,68 persen hal ini menunjukkan bahwa sebagian dari responden merupakan usia produktif dalam bekerja dan mampu memberikan lebih banyak ide-ide inovativ.

Karakteristik responden berdasarkan tingkat pendidikan yang paling dominan adalah responden dengan tingkat pendidikan terakhir D1/D2 yaitu 47,46 
Putu Aprilia Candra Dewi, Pengaruh Pelatihan...

persen. Hal ini menunjukan bahwa responden dengan pendidikan D1/D2 dengan presentase paling banyak karena berasal dari pendidikan perhotelan yang memang benar-benar dibutuhkan di Hotel Natya Kuta.

Sebelum dilakukan uji regresi linear berganda, dilakukan uji instrumen terlebih dahulu. Instrumen yang valid berarti instrumen yang dapat digunakan untuk mengukur apa yang seharusnya diukur. Tinggi rendahnya validitas menunjukan sejauh mana data yang terkumpul tidak menyimpang dari gambarangambaran tentang variabel yang dimaksud.

Tabel 4.

Hasil Uji Instrumen Validitas

\begin{tabular}{|c|c|c|c|c|}
\hline No & Variabel & $\begin{array}{c}\text { Item } \\
\text { Pernyataan }\end{array}$ & $\begin{array}{c}\text { Koefisien } \\
\text { Korelasi }\end{array}$ & Keterangan \\
\hline \multirow[t]{4}{*}{1} & Produktivitas (Y) & Y.1 & 0,470 & Valid \\
\hline & & Y.2 & 0,711 & Valid \\
\hline & & Y.3 & 0,660 & Valid \\
\hline & & Y.4 & 0,767 & Valid \\
\hline \multirow{5}{*}{2} & Pelatihan $\left(\mathrm{X}_{1}\right)$ & Y.5 & 0,740 & Valid \\
\hline & & $\mathrm{X}_{1.1}$ & 0,678 & Valid \\
\hline & & $\mathrm{X}_{1} .2$ & 0,740 & Valid \\
\hline & & $\mathrm{X}_{1} .3$ & 0,739 & Valid \\
\hline & & $\mathrm{X}_{1.4}$ & 0,718 & Valid \\
\hline \multirow{10}{*}{3} & Motivasi $\left(\mathrm{X}_{2}\right)$ & $X_{1.5}$ & 0,728 & Valid \\
\hline & & $\mathrm{X}_{2.1}$ & 0,519 & Valid \\
\hline & & $\mathrm{X}_{2.2}$ & 0,466 & Valid \\
\hline & & $\mathrm{X}_{2.3}$ & 0,719 & Valid \\
\hline & & $X_{2.4}$ & 0,713 & Valid \\
\hline & & $\mathrm{X}_{2.5}$ & 0,562 & Valid \\
\hline & & $\mathrm{X}_{2 .} 6$ & 0,395 & Valid \\
\hline & & $\mathrm{X}_{2.7}$ & 0,491 & Valid \\
\hline & & $\mathrm{X}_{2.8}$ & 0,549 & Valid \\
\hline & & $\mathrm{X}_{2.9}$ & 0,460 & Valid \\
\hline \multirow{10}{*}{4} & Lingkungan Kerja Fisik & $X_{2 .} 10$ & 0,583 & Valid \\
\hline & $\left(X_{3}\right)$ & $\mathrm{X}_{3.1}$ & 0,479 & Valid \\
\hline & & $\mathrm{X}_{3.2}$ & 0,424 & Valid \\
\hline & & $\mathrm{X}_{3.3}$ & 0,422 & Valid \\
\hline & & $X_{3.4}$ & 0,455 & Valid \\
\hline & & $X_{3.5}$ & 0,455 & Valid \\
\hline & & $X_{3} 6$ & 0,490 & Valid \\
\hline & & $X_{3 .} 7$ & 0,448 & Valid \\
\hline & & $\mathrm{X}_{3.8}$ & 0,547 & Valid \\
\hline & & $\mathrm{X}_{3.9}$ & 0,51 & Valid \\
\hline
\end{tabular}

Sumber: Data diolah, 2017 
Hasil uji validitas instrumen penelitian disajikan pada Tabel 4 yang menunjukkan bahwa seluruh indikator dalam variabel pelatihan, motivasi, lingkungan kerja fisik, dan produktivitas karyawan memiliki nilai Pearson Correlation yang lebih besar dari angka 0,30 sehingga seluruh indikator tersebut dikatakan telah memenuhi syarat validitas data.

Insturumen yang reliable adalah suatu instrument yang bila digunakan beberapa kali untuk mengukur objek yang sama, maka akan menghasilkan data yang sama. Instrument dikatakan reliable untuk mengukur variabel bila memiliki nilai Cronbach Alpha > 0,60.

Tabel 5.

Hasil Uji Reliabilitas

\begin{tabular}{clcc}
\hline No & \multicolumn{1}{c}{ Variabel } & $\begin{array}{c}\text { Nilai Cronbach's } \\
\text { Alpha }\end{array}$ & Keterangan \\
\hline 1 & Produktivitas & 0,767 & Reliabel \\
2 & Pelatihan & 0,742 & Reliabel \\
3 & Motivasi & 0,731 & Reliabel \\
4 & Lingkungan Kerja Fisik & 0,702 & Reliabel \\
\hline \multicolumn{2}{l}{ Sumber: } & Data diolah, 2017
\end{tabular}

Hasil uji reliabilitas instrumen pada penelitian ini disajikan pada Tabel 5 yang menunjukkan bahwa keempat instrumen penelitian yaitu pelatihan, motivasi, lingkungan kerja fisik, dan produktivitas karyawan memiliki koefisien cronbach's alpha yang lebih besar dari angka 0,60 sehingga pernyataan pada kuesioner dapat dikatakan reliabel.

Selanjutnya dilakukan uji asumsi klasik seperti uji normalitas, heterokedastisitas, multikolinearitas. Uji normalitas berdasarkan hasil analisis, diperoleh hasil sebesar $0,627>0,05$ yang artinya data berdistribusi normal. Uji heteroskedastisitas menunjukan hasil lebih besar dari 0.05 yang berati maka dapat disimpulkan bahwa dalam model tersebut tidak terdapat heteroskedastitas, 
sehingga layak digunakan unuk memprediksi variabel dependen. Berdasarkan hasil analisis, dapat dilihat bahwa koefisien Tolerance semua variabel lebih besar dari 0,10 dan nilai VIF yang lebih kecil dari 10. Hasil ini mengindikasikan bahwa tidak terdapat gejala multikolinear dari model regresi yang dibuat.

Metode regresi linier beranda digunakan dalam penelitian ini untuk mengetahui pengaruh Pelatihan $\left(\mathrm{X}_{1}\right)$, Motivasi $\left(\mathrm{X}_{2}\right)$, Lingkungan Kerja $\left(\mathrm{X}_{3}\right)$ dan Produktivitas Karyawan (Y). Metode ini diuji menggunakan sistem komputer berupa SPSS 21 For Windows, maka diperoleh hasil seperti tabel dibawah ini :

Tabel 6.

Analisis Regresi Linier Berganda

\begin{tabular}{|c|c|c|c|c|c|c|}
\hline \multirow[t]{2}{*}{ Mod } & & \multicolumn{2}{|c|}{ Unstandardized Coefficients } & \multirow{2}{*}{$\begin{array}{c}\text { Standardized } \\
\text { Coefficients }\end{array}$} & \multirow[t]{2}{*}{$\mathbf{t}$} & \multirow[t]{2}{*}{ Sig. } \\
\hline & & B & Std. Error & & & \\
\hline \multirow{4}{*}{1} & (Constant) & 4.388 & 3.838 & .342 & 1.143 & .258 \\
\hline & $\mathrm{X} 1$ & .192 & .073 & .445 & 2.606 & .014 \\
\hline & $\mathrm{X} 2$ & .288 & .096 & .276 & 2.993 & .004 \\
\hline & $\mathrm{X} 3$ & .259 & .109 & & 2.378 & .023 \\
\hline
\end{tabular}

Sumber: Data diolah, 2017

Tabel 6 dapat diketahui persamaan regresi yang diperoleh adalah:

$\mathrm{Y}=4,388+0,192 \mathrm{X}_{1}+0,288 \mathrm{X}_{2}+0,259 \mathrm{X}_{3}$

Berdasarkan persamaan yang diperoleh pada variabel pelatihan nilai beta 0,342, signifikan sebesar 0,014, variabel motivasi memiliki nilai beta 0,445 , signifikan sebesar 0,004 dan variabel lingkungan kerja fisik memiliki nilai beta 0,276, signifikan sebesar 0,023, dengan demikian dapat disimpulkan bahwa pelatihan, motivasi, dan lingkungan kerja fisik mempunyai pengaruh positif dan signifikan terhadap produktivitas karyawan di Hotel Natya Kuta. 
Uji F memiliki tujuan untuk menunjukkan kelayakan model regresi linier berganda sebagai alat analisis yang menguji pengaruh variabel bebas terhadap variabel terikat. Hasil yang diperoleh adalah sebagai berikut.

Tabel 7.

Analisis Pengujian Secara Bersama (Uji F)

\begin{tabular}{rlrrrrr}
\hline Model & & Sum of Squares & Df & Mean Square & F & Sig. \\
\hline \multirow{3}{*}{1} & Regression & 62.546 & 3 & 20.849 & 7.123 & $.000^{\mathrm{b}}$ \\
& Residual & 160.980 & 55 & 2.927 & & \\
& Total & 223.525 & 58 & & & \\
\hline
\end{tabular}

Sumber: Data diolah, 2017

Uji F dilakukan dengan melihat nilai signifikansi pada tabel anova. Berdasarkan hasil uji, nilai signifikansi $\mathrm{F}$ adalah sebesar 0,000 yang lebih kecil dari $0,05(\mathrm{~F}<\alpha)$ maka model ini dikatakan layak atau variabel bebas mampu menjelaskan variabel terikat. Selanjutnya dilakukan uji koefisien determinasi untuk mengetahui seberapa besar variabel $\mathrm{x}$ memengaruhi variabel $\mathrm{y}$. hasil koefisien determinasi dapat dilihat dalam tabel sebagai berikut.

Tabel 8.

Analisis Data Koefisien Determinasi $\left(\mathbf{R}^{2}\right)$

\begin{tabular}{llrrr}
\hline Model & R & R Square & $\begin{array}{c}\text { Adjusted R } \\
\text { Square }\end{array}$ & $\begin{array}{l}\text { Std. Error of } \\
\text { the Estimate }\end{array}$ \\
\hline 1 & $.516^{\mathrm{a}}$ & .443 & .341 & 1.711 \\
\hline Sumber: Data diolah, 2017 & & &
\end{tabular}

Berdasarkan hasil uji pada tabel 8 besarnya nilai adjusted $\mathrm{R}$ square adalah sebesar 0,341 yang artinya sebesar 44,3 persen variasi produktivitas karyawan dipengaruhi oleh pelatihan, motivasi, dan lingkungan kerja fisik, sedangkan sisanya sebesar 55,7 persen dipengaruhi oleh faktor-faktor lain yang tidak dimasukkan ke dalam model penelitian.

Berdasarkan hasil analisis data diperoleh bahwa pelatihan berpengaruh positif dan signifikan terhadap produktivitas karyawan dengan hasil (Sig. t, 0,014 
$\leq 0,05)$ serta koefisien beta sebesar 0,342 yang menunjukan bahwa pelatihan secara positif berpengaruh signifikan terhadap produktivitas karyawan Hotel Natya Kuta. Hal tersebut berarti bahwa semakin baik pelatihan maka semakin tinggi produktivitas karyawan Hotel Natya Kuta. Pernyataan ini didukung dengan temuan dari Kaswan (2011), Mangkunegara (2016), Neelam et al. (2014), Singh et al. (2014), dan Widianto (2016) yang menyatakan bahwa pelatihan berpengaruh positif dan signifikan terhadap produktivitas karyawan. Berdasarkan hasil yang diperoleh maka hipotesis pengaruh pelatihan terhadap produktivitas karyawan dapat diterima.

Berdasarkan hasil analisis data diperoleh bahwa motivasi berpengaruh positif dan signifikan terhadap produktivitas karyawan dengan hasil (Sig. t, 0,004 $\leq 0,05)$ serta koefisien beta sebesar 0,445 yang menunjukan bahwa motivasi secara positif berpengaruh signifikan terhadap produktivitas karyawan Hotel Natya Kuta. Pernyataan ini didukung dengan temuan dari Mangkunegara (2016), Chaudhary et al. (2012), Chukuma et al. (2014), dan Ardana (2016) yang menyatakan bahwa motivasi berpengaruh positif dan signifikan terhadap produktivitas karyawan. Berdasarkan hasil yang diperoleh maka hipotesis pengaruh motivasi terhadap produktivitas karyawan dapat diterima.

Berdasarkan hasil analisis data diperoleh hasil bahwa lingkungan kerja fisik berpengaruh positif dan signifikan terhadap produktivitas karyawan dengan hasil (Sig. t, $0,023 \leq 0,05$ ) serta koefisien beta sebesar 0,276 yang menunjukan bahwa lingkungan kerja fisik secara positif berpengaruh signifikan terhadap kinerja karyawan Hotel Natya Kuta. Pernyataan ini didukung dengan temuan dari 
Desmoda (2016), Sehgal (2012), Awan (2015), dan Lestari dkk (2013) yang menyatakan bahwa lingkungan kerja fisik berpengaruh positif dan signifikan terhadap produktivitas karyawan. Berdasarkan hasil yang diperoleh maka hipotesis pengaruh lingkungan kerja fisik terhadap karyawan dapat diterima.

\section{SIMPULAN DAN SARAN}

Berdasarkan hasil pembahasan penelitian yang telah dilakukan, maka dapat disimpulkan bahwa: 1). Pelatihan berpengaruh positif dan signifikan terhadap produktivitas karyawan di Hotel Natya Kuta; 2). Motivasi berpengaruh positif dan signifikan terhadap produktivitas karyawan di Hotel Natya Kuta; 3). Lingkungan Kerja Fisik berpengaruh positif dan signifikan terhadap produktivitas karyawan di Hotel Natya Kuta.

Adapun yang dapat di sarankan dari penelitian ini yakni manajemen Hotel Natya Kuta sebaiknya mengawasi dan memberikan dorongan pada karyawan agar karyawan mampu mengerjakan sebagaian tugas dari total pekerjaan tiap harinya. Manajemen Hotel Natya Kuta sebaiknya meningkatkan materi yang diberikan pada saat melakukan pelatihan agar karyawan mampu untuk mengembangkan kemampuannya dalam bekerja dan merasa diuntungkan dengan pelatihan yang diterima.

Kemudian, perusahaan sebaiknya memberikan kesempatan pada karyawan untuk mengembangkan potensi diri mereka, ini penting dilakukan agar karyawan mampu memiliki keterampilan tertentu dalam bekerja. Lingkungan kerja fisik memiliki pengaruh secara positif dan signifikan terhadap produktivitas, oleh karena itu manajer sebaiknya lebih memerhatikan keadaan lingkungan fisik 
disekitar yaitu dengan penggunaan warna yang dapat menimbulkan kenyamanan saat bekerja dan tata letak ruangan yang strategis sehingga karyawan dapat bekerja dengan baik.

\section{DAFTAR RUJUKAN}

Ahyari, Agus. 2007. Manajemen Produksi Sistem Produksi. Buku 2. Yogyakarta: BPFE.

Al-Shammari, Serhan A. 2015. The Effect of Work Environment on Employees Productivity, International Journal of Science and Research (IJSR), 4 (5), 2319-7064.

Ardana, I Komang, Ni Wayan Mujiati, dan I Wayan Mudiarta Utama. 2012. Manajemen Sumber Daya Manusia. Yogyakarta: Graha Ilmu.

Armstrong, M., Human Resource Management. 2009, London: Kogan Page Limited.

Awan, Abdul Ghafoor. 2015. Impact Of Working Environment On Employee's Productivity: A Case Study Of Banks And Insurance Companies In Pakistan. European Journal of Business and Management. 7 (1), 22222839.

Biech, Elaine. 2005. Training for Dummies by Elaine Beich. London: ASTD

Budiartha, Bagia, dan Suwendra. 2015. Pengaruh Pelatihan Dan Motivasi Kerja Terhadap Produktivitas Kerja Karyawan. E-Journal Bisma Universitas Pendidikan Ganesha Jurusan Manajemen, 3 (1), 2513-2563.

Chaudhary, Nupur and Bharti Sharma. 2012. Impact of Employee Motivation on Performance (Productivity) In Private Organization. International Journal of Business Trends and Technology, 2 (4), 2249-0183.

Chukwuma, Edwin Maduka and Obiefuna Okafor. 2014. Effect of Motivation on Employee Productivity: A Study of Manufacturing Companies in Nnewi. International Journal of Managerial Studies and Research (IJMSR), 2 (7), 137-147. 
Desmonda, Agustin Ana. 2016. Pengaruh Lingkungan Kerja Fisik Terhadap Produktivitas Kerja Karyawan Pada PT. Federal International Finance Cabang Samarinda. Journal Administrasi Bisnis, 4 (4), 1179-1193.

Dewi, Sri Kurniawati Padma, dan Laras, Titi. 2014. Pengaruh Pelatihan, Motivasi Kerja Dan Lingkungan Kerja Terhadap Kinerja Karyawan Koperasi Mahasiswa (Kopma) Di Kabupaten Sleman. Efektif Jurnal Bisnis dan Ekonomi, 5, $48-72$.

Edy. 2008. Pengaruh Budaya Organisasional dan Lingkungan Kerja Terhadap Kinerja Perawat "Rumah Sakit Mata Dr. YAP" Yogyakarta dengan Motivasi dan Kepuasan Kerja sebagai Variabel Pemediasi. Jurnal Ekonomi dan Bisnis, 2 (3), 159-174.

Elnaga, Amin and Amir Imran. 2013. The Effect of Training on Employee Performance. European Journal of Bussinnes and Management, 5 (2), 137-147.

Ferreira, A., and Du Plessis, T. 2009. Effect of Online Social Networking on Employee Productivity. South African Journal of Information Management, 11 (1), 1-11.

Ghafoor, B., T., \& Tsegaye, A. 2014. The Effect of Employee's Fairness Perception on Their Satisfaction towards the Performance Appraisal Practies (A Case Study of University of Gondar). International Journal of Management and Commerce Innovations, 2 (1), 174-210.

Hammed, A., and Amjad, S. 2009. Impact of Office Design on Employees Productivity: A Case Study of Banking Organization of Abbottabad, Pakistan. Journal of Public Affairs, Administration and Management, 3 (1), 1-13.

Hanaysha, Jalal. 2016. Testing the Effects of Employee Empowerment, Teamwork, and Employee Training on Employee Productivity in Higher Education Sector. International Journal of Learning \& Development, 6 (1), 2164-4063.

Hariawati, Erlina. 2009. Pengaruh Pelatihan Kerja Terhadap Peningkatan Prestasi Kerja Karyawan PT. Mandom Indonesia Tbk. Jurnal Manajemen Sumber Daya Manusia, 1 (1), 107-119. 
Putu Aprilia Candra Dewi, Pengaruh Pelatihan...

Hasibuan. 2010. Organisasi dan Motivasi. Jakarta: PT Bumi Aksara.

Holle. 2012. Relationship Between the Physical Environment and Different Domains of Physical Activity in European adults: A Systematic Review. BMC Public Health, 12 (807), 1-18.

Kaswan. 2011. Pelatihan dan Pengembangan. Cetakan Satu. Bandung: Alfabeta.

Kawara, P. 2014. Effects Of Reward System On Employee Productivity In Catholic University Of Eastern Africa. International Journal of Recent Research in Commerence Economics and Management, 1 (2), 1-4.

Kartika, Endo Wijaya dan Thomas S. Kaihatu. 2010. Analisis Pengaruh Motivasi Kerja Terhadap Kepuasan Kerja (Studi Kasus pada Karyawan Restoran di Pakuwon Food Festival Surabaya). Jurnal Manajemen dan Kewirausahaan, 12 (1), 100-112

Khan Ahmad Khan, Muazzam Ali, Hafiz Hussain, dan Safdar Bilal Safdar. 2015. Impact of Employee Training and Motivation on Business Development in Banking Sector in Pakistan. Study Conducted in Pakistan. American Journal of Business, Economics and Management, 3 (5), 241-249.

Khan, Gautam, Shalini. 2014. A Study of Impact of Motivation on Productivity of Employee. The International Journal of Business \& Management, 2 (12), 2512-2536

Komarudin, Encyclopedia of Management. 2002, Jakarta: Bumi Aksara.

Konings, Jozef and Stijn Vanormelingen. 2015. The Impact Of Training On Productivity And Wages: Firm-Level Evidence. The Review of Economics and Statistics, 97 (2), 485 - 497.

Lewa, Eka Idham lip K, dan Subowo. 2005. Pengaruh Kepemimpinan, Lingkungan Kerja Fisik, dan Kompensasi terhadap Kinerja Karyawan di PT. Pertamina (Persero) Daerah Operasi Hulu Jawa Bagian Barat, Cirebon. Sinergi, Kajian Bisnis dan Manajemen, 9 (8), 129-140.

Mangkunegara, Anwar Prabu. 2011. Manajemen Sumber Daya Manusia Perusahaan. Bandung: Remaja Rosdakarya.

Mangkunegara, Anwar Prabu, dan Agustine, Rela. 2016. Effect of Training, Motivation and Work Environment on Physicians' Performance. Academic 
Journal of Interdisciplinary Studies MCSER Publishing, Rome-Italy. 5 (1), 2281-399.

Mullins, J.L., Management and Organizational Behavior. 2005, London: Prentice Hall.

Neelam, Khan Yousafzai, Shahid Jan, dan Hashim. 2014. The Impact of Training and Development on Employees Performance and Productivity A case study of United Bank Limited Peshawar City, KPK, Pakistan. International. Journal of Academic Research in Business and Social Sciences. 4 (4), 2222-6990

Nitisemito, Alex S. 2000. Manajemen Personalia. Jakarta: Ghalia Indonesia

Putra, I Made Wijanu dan I Komang Ardana. 2016. Pengaruh Motivasi Serta Lingkungan Kerja Terhadap Kepuasan Kerja Serta Dampaknya Terhadap Produktivitas Perajin Perak. E-Jurnal Manajemen Unud. 5 (12), 23028912

Robbins, Stephen P dan Timothy A. Judge. 2008. Perilaku Organisasi. Edisi 12. Jakarta: Salemba Empat.

Sabir, R. I., Akhtar, N., Bukhari, F.A.S., Nasir J., and Ahmed, W. 2014. Impact Of Training On Productivity Of Employees: A Case study of electricity supply company in Pakistan. International Review of Management and Business Research, 3 (2), 595-606.

Sastradipoera, K., Training and Development: Human Resource Management Approach. 2006. Bandung: Kappa Sigma.

Sedarmayanti. 2009. Manajemen Sumber Daya Manusia. Bandung: PT. Refika Aditama. 2009. Tata Kerja Dan Produktivitas Kerja. Cetakan kedua. Bandung: CV. Mandar Maju. 2010. Sumber Daya Manusia dan Produktivitas Kerja. Bandung: CV. Mandar Maju.

Sehgal, Shruti. 2012. Relationship between Work Enviornment And Productivity. International Journal of Engineering Research and Applications (IJERA). 2 (4), 1992-1995 
Siagian, Sondang P. 2002. Fungsi-fungsi Manajerial. Jakarta: Rineka Cipta

Singh dan Mohanty, Madhumita. 2012. Impact of Training Practices on Employee Productivity: A Comparative Study. Interscience Management Review (IMR). 2 (2), 1256-1261

Singh, Prashant. 2014. Increasing Productivity with Motivation In The Workplace. National Monthly Refereed Journal Of Research In Commerce \& Management. 6 (2), 2277-1166.

Sjafri Mangku Prawira, Aida Hubies. 2007. Manajemen Mutu, SDM. Bogor: PT. Ghalia Indonesia.

Sugiono. 2016. Metode Penelitian Administrasi. Bandung: Alfabeta.

Sukmawati, Ferina. 2008. Pengaruh Kepemimpinan, Lingkungan Kerja Fisik dan Kompensasi terhadap Kinerja Karyawan di PT. Pertamina (Persero) UPMS III Terminal Transit Utama Balongan, Indramayu. Jurnal Ekonomi \& Bisnis, 2 (3), 175-193.

Sutanto, Eddy Madiono, dan Patty, Ferdian Mario. 2014. Persepsi Akan Gaji, Motivasi Kerja, Dan Kinerja Karyawan Pt. Amita Bara Sejahtera. Journal of Business and Banking. 4, 1-14.

Sutrisno, Edy. 2009. Manajemen Sumber Daya Manusia. Edisi Pertama. Cetakan Ketiga. Jakarta: Kencana.

2010. Manajemen Sumber Daya Manusia. Edisi Pertama. Cetakan Kedua. Jakarta: Kencana.

Wibowo. 2014. Manajemen Kinerja. Edisi Keempat. Jakarta: Penerbit PT Raja Grafindo Persada.

Widianto, Joko Tri. 2016. Pengaruh Pelatihan Terhadap Produktivitas Kerja Pegawai (Studi Padaajb Bumiputera 1912 Kantor Cabang Syariah Serang). Jurnal Ilmiah Revenue, 2 (2), 2442 - 8493

Winardi. 2008. Motivasi dan Pemotivasian Dalam Manajemen Jakarta: Raja Grafindo Jakarta 